\title{
Effects of foliar applications of nitric oxide and spermidine on chlorophyll fluorescence, photosynthesis and antioxidant enzyme activities of citrus seedlings under salinity stress
}

\author{
D. KHOSHBAKHT ${ }^{*},+$, M. R. ASGHARI ${ }^{*}$, and M. HAGHIGHI ${ }^{* *}$ \\ Department of Horticultural Science, College of Agriculture, Urmia University, West Azarbaijan, Iran* \\ Department of Horticulture Science, College of Agriculture, Isfahan University of Technology, Isfahan, Iran ${ }^{* *}$
}

\begin{abstract}
The effects of exogenous sodium nitroprusside (SNP), as nitric oxide donor, and spermidine (Spd) on growth and photosynthetic characteristics of Bakraii seedlings (Citrus reticulata $\times$ Citrus limetta) were studied under $\mathrm{NaCl}$ stress. In citrus plants, SNP- and Spd-induced growth improvement was found to be associated with reduced electrolyte leakage, malondialdehyde, hydrogen peroxide content, and leaf $\mathrm{Na}^{+}$and $\mathrm{Cl}^{-}$concentration. However, we found increased leaf $\mathrm{Ca}^{2+}$, $\mathrm{Mg}^{2+}$, and $\mathrm{K}^{+}$concentrations, relative water content, chlorophyll fluorescence parameters, antioxidant enzyme activities, such as ascorbate peroxidase, catalase, superoxide dismutase and peroxidase, as well as higher photosynthetic rate, intercellular $\mathrm{CO}_{2}$ concentration, stomatal conductance, and transpiration rate under saline regime. Foliar application of SNP and Spd alone mitigated the adverse effect of salinity, while the combined application proved to be even more effective.
\end{abstract}

Additional key words: abiotic stress; biomass; gas exchange; oxidative stress; photosystem II efficiency.

\section{Introduction}

Salinity is one of the major environmental stresses for plants that can severely limit crop production throughout the world (Sudhir and Murthy 2004, Ravindran et al. 2007, Munns and Tester 2008). Salinity stress has received increasing attention in recent years because it greatly reduces agricultural productivity (Parihar et al. 2015). Salinity causes various injuries in plants, such as tissue burning, yield reduction, and finally plant death (RomeroAranda et al. 2001), causes leaf senescence, reduction PSII activities (Khayyat et al. 2016), enhances membrane permeability (Dhindsa et al. 1981), nutritional imbalances, and toxicity (Khoshbakht et al. 2014). $\mathrm{NaCl}$ inhibits photosynthetic rate $\left(P_{\mathrm{N}}\right)$ as a consequence of osmotic stress, which leads to a decrease in water potential and stomatal conductance $\left(g_{\mathrm{s}}\right)$, sugar accumulation, which causes feedback inhibition, and ion toxicity (e.g., an excess of $\mathrm{Na}^{+}$and $\mathrm{Cl}^{-}$) accompanied by a reduction of $\mathrm{K}^{+}$and $\mathrm{Ca}^{2+}$ (Khoshbakht and Asgharei 2015a). Moreover, salinity can cause oxidative stress through excessive production of reactive oxygen species (ROS), such as superoxide radical $\left(\mathrm{O}_{2}{ }^{-}\right)$, hydroxyl radicals $\left({ }^{\circ} \mathrm{OH}\right)$, and hydrogen peroxide $\left(\mathrm{H}_{2} \mathrm{O}_{2}\right)$ (Wu et al. 2011). The accelerated accumulation of ROS is able to induce oxidative damage to many cellular constituents, such as proteins, membrane lipids, and nucleic acids (Mittler 2002). One of the most destructive impacts of oxidative damage is peroxidation of membrane lipids, which leads to the accompanying generation of malondialdehyde (MDA) (Wu et al. 2011). Consequently, a high MDA content is a helpful biomarker of lipid peroxidation and is therefore often used to detect oxidative

Received 30 June 2017, accepted 3 January 2018, published as online-first 21 June 2018.

${ }^{+}$Corresponding author; phone: +98 311 3913447, fax: +98 311 3913356, e-mail: davod.khoshbakht@gmail.com

Abbreviations: APX - ascorbate peroxidase; $C_{\mathrm{a}}$ - atmospheric $\mathrm{CO}_{2}$ concentration; $C_{\mathrm{i}}$ - intercellular $\mathrm{CO}_{2}$ concentration; $\mathrm{CAT}$ - catalase; $\mathrm{Chl}$ - chlorophyll; $E$ - transpiration rate; $\mathrm{EL}$ - electrolyte leakage; $\mathrm{F}_{0}$ - minimal fluorescence yield of the dark-adapted state; $\mathrm{F}_{\mathrm{m}}$ - maximal fluorescence yield of the dark-adapted state; $F_{\mathrm{v}}$ - variable fluorescence; $F_{v} / F_{m}$ - maximum photochemical efficiency of PSII; $g_{\mathrm{s}}$ - stomatal conductance; LN - number of leaves per plant; MDA - malondialdehyde; NPQ - nonphotochemical quenching; PAs - polyamines; Put - putrescine; POD - peroxidase; $P_{\mathrm{N}}$ - net photosynthetic rate; qP - photochemical quenching; ROS - reactive oxygen species; RWC - relative water content; SL - length of shoot; SNP - sodium nitroprusside; SOD - superoxide dismutase; S salinity stress; Spd - spermidine; Spm - spermine; TPDM - total plant dry mass; TPFM - total plant fresh mass.

Acknowledgements: Here we would like to thank to the Department of Horticulture, College of Agriculture, University of Urmia for financial support of the research. 
stress situations induced by salinity (Almansa et al. 2002). Salt stress alters the critical balance between the production of ROS and the quenching activity of antioxidants, resulting in oxidative stress that causes damage to plants (Hernández et al. 1999). To control the content of ROS, plants possess a well-developed and intricate antioxidant defense system including enzymatic and nonenzymatic antioxidative processes (Blokhina et al. 2003). Citrus plants are known to be sensitive to salts because of the specific toxicity of $\mathrm{Cl}^{-}$and/or $\mathrm{Na}^{+}$and to the osmotic effect caused by the high concentration of salts (Koshbakht et al. 2015b).

The polyamines (PAs) such as putrescine (Put), Spd and spermine $(\mathrm{Spm})$ are low-molecular-mass polycations ubiquities in all living organisms (Kusano et al. 2008). Some reports have indicated the relationships between PAs and environmental stress (Galston et al. 1997, Bouchereau et al. 1999). Biosynthesis of PAs may be an integral part of plant's response to salinity stress (Alcázar

\section{Materials and methods}

Plant material, growth conditions, salinity, Spd and SNP treatments: The experiment was carried out under a greenhouse conditions. After germination, seedlings (sixmonth-old plants) of Iranian mandarin Bakraii (Citrus reticulata $\times$ Citrus limetta) were transplanted into $30 \mathrm{~cm}$ wide plastic pots containing fine sand, then placed in a greenhouse at $25-28 / 17^{\circ} \mathrm{C}$ (day/night) temperatures, $800 \mu \mathrm{mol}$ (photon) $\mathrm{m}^{-2} \mathrm{~s}^{-1}$ maximum PAR, 60/70 $\pm 5 \%$ relative humidity, and a $12-\mathrm{h}$ photoperiod. Plants were irrigated with $0.6 \mathrm{~L}$ of water and fertilized with a commercial water soluble fertilizer containing macro- and micronutrients (Floral Mixed fertilizer, IFO, Italy). After the acclimation period of at least six months, (twelve months after seed germination), seedlings were sprayed at two-week interval, (for the first time it was two weeks before the onset of salinity treatment), with water (control) or with $0.5 \mathrm{mM}$ SNP or/and with $0.5 \mathrm{mM}$ Spd until both sides of all their leaves were completely wet (run-off). The $\mathrm{NaCl}$, SNP, and Spd treatments were as follows:

\begin{tabular}{llll}
\hline Treatment & $\mathrm{NaCl}[\mathrm{mM}]$ & $\mathrm{SNP}[\mathrm{mM}]$ & $\mathrm{Spd}[\mathrm{mM}]$ \\
\hline Control (C) & 0 & 0 & 0 \\
NaCl (S) & 75 & 0 & 0 \\
S + SNP & 75 & 0.5 & 0 \\
S + Spd & 75 & 0 & 0.5 \\
S + SNP + Spd & 75 & 0.5 & 0.5 \\
\hline
\end{tabular}

Two weeks after the foliar application of SNP or/and Spd, all seedlings were exposed to salt treatments. Salt treatments $(0$ and $75 \mathrm{mM}$ of $\mathrm{NaCl})$ were added to the pots using $0.5 \mathrm{~L}$ of irrigation water. To avoid osmotic shock, the $\mathrm{NaCl}$ concentration was increased gradually. $60 \mathrm{~d}$ after the salt treatment, various analyses were performed. et al. 2010). Increasing PAs biosynthesis might protect the plants from salinity by removing free radicals, maintaining membrane and cellular structures, keeping a cation-anion balance (Bouchereau et al. 1999), regulation of ion channels and induction of ATP synthesis (Lopatin et al. 1994).

Nitric oxide (NO) is a bioactive molecule that plays a critical role in many physiological processes including germination, growth, and flowering (Lamattina et al. 2003). It was reported that application of the SNP, as nitric oxide (NO) donor, significantly increased salt tolerance through stimulating the activities of $\mathrm{H}^{+}$-ATPase and $\mathrm{Na}^{+} / \mathrm{H}^{+}$antiporter in the tonoplast (Zhao et al. 2004). The protective function of NO includes the regulation of ROS and antioxidants, induction of gene expression, and absorption and distribution of elements (Arasimowicz and Floryszak-Wieczorek 2007). We investigated the effects of SNP, as NO donor, and Spd on alleviating the injury to citrus seedlings and its relevant mechanism under $\mathrm{NaCl}$ stress.

Growth characteristics: At the end of experiment, after measuring the shoot length (SL), plants were harvested and leaf number (LN) was counted. Then plants were washed with distilled water in order to remove adhering foreign particles. The total plant fresh mass (TPFM) were recorded, and the samples were dried separately at $80^{\circ} \mathrm{C}$ for $48 \mathrm{~h}$; total plant dry mass (TPDM) were then recorded.

Leaf tissue mineral analysis: At the end of experiment, leaves of each plant were separated and washed with deionized water. Tissues were oven dried at $70^{\circ} \mathrm{C}$ for $3 \mathrm{~d}$ and dried parts were milled to a powder for mineral nutrient analysis. Ground samples were ashed in porcelain crucibles at $550^{\circ} \mathrm{C}$ for $6 \mathrm{~h}$. The white ash was mixed with $2 \mathrm{ml}$ of hot $\mathrm{HCl}$, filtered into a $100-\mathrm{ml}$ volumetric flask, and made up to $100 \mathrm{ml}$ with distilled water. Concentrations of $\mathrm{Na}^{+}$and $\mathrm{K}^{+}$were determined by flame photometry (Model PFP7, Jenway, UK). $\mathrm{Ca}^{2+}$ and $\mathrm{Mg}^{2+}$ concentrations were measured by using an atomic absorption spectrophotometer (Perkin Elmper Analyst Model 200, USA). $\mathrm{Cl}^{-}$was extracted from $500 \mathrm{mg}$ DM of leaf tissue with $0.1 \mathrm{M} \mathrm{HNO}_{3}$ in $10 \%(\mathrm{v} / \mathrm{v})$ glacial acetic acid and samples were incubated overnight at room temperature and then filtered. Finally, $\mathrm{Cl}^{-}$concentration was determined by silver ion titration (Moya et al. 1999).

Assays of the antioxidant enzyme activities: Frozen leaf segments $(0.5 \mathrm{~g})$ were homogenized in $10 \mathrm{ml}$ of $50 \mathrm{mM}$ potassium phosphate buffer, $\mathrm{pH} 7.0$, containing $1 \mathrm{mM}$ ethylenediaminetetraacetic acid (EDTA), and 1\% soluble polyvinylpyrrolidone (PVP), with the addition of $1 \mathrm{mM}$ ascorbate in the case of APX assay. The homogenate was centrifuged at $15,000 \times g$ for $20 \mathrm{~min}$ at $4^{\circ} \mathrm{C}$ and the supernatant was immediately frozen under liquid $\mathrm{N}_{2}$ and 
stored at $-70^{\circ} \mathrm{C}$ for the following assays.

Total protein content of leaf samples was determined using the method described by Bradford (1976). The tubes containing the extract and Bradford reagent were incubated at room temperature for $30 \mathrm{~min}$, thoroughly mixed, and measured at $595 \mathrm{~nm}$ by spectrophotometer (U-2000, Hitachi Instruments, Tokyo, Japan) and compared to bovine serum albumin (BSA) as a standard.

Total superoxide dismutase (SOD, EC 1.15.1.1) activity was assayed by monitoring the inhibition of photochemical reduction of nitroblue tetrazolium (NBT) according to the method of Beauchamp and Fridovich (1971). The $3 \mathrm{ml}$ of reaction mixture contained $50 \mathrm{mM}$ potassium phosphate buffer ( $\mathrm{pH} 7.8$ ), $13 \mathrm{mM}$ methionine, $75 \mu \mathrm{M}$ NBT, $2 \mu \mathrm{M}$ riboflavin, $0.1 \mathrm{mM}$ EDTA, and $100 \mu \mathrm{l}$ of enzyme extract. The reaction mixtures were illuminated for $15 \mathrm{~min}$ at a light intensity of $15 \mathrm{~W}$ fluorescent lamps for the initiation of reaction. One unit of SOD activity was defined as the amount of enzyme required to cause $50 \%$ inhibition of the reduction of NBT monitored at $560 \mathrm{~nm}$ using a spectrophotometer (U-2000, Hitachi Instruments, Tokyo, Japan). The amount of enzyme that inhibited 50\% of NBT photo reduction was expressed as one unit of SOD activity. SOD activity was expressed as unit per mg of protein.

Catalase (CAT, EC 1.11.1.6) activity was determined spectrophotometrically (U-2000, Hitachi Instruments, Tokyo, Japan) by following the decrease of absorbance of $\mathrm{H}_{2} \mathrm{O}_{2}$ at $240 \mathrm{~nm}$ (extinction coefficient is $39.4 \mathrm{mM}^{-1} \mathrm{~cm}^{-1}$ ) as described by Aebi (1984) with slight modifications. The reaction mixture contained $50 \mathrm{mM}$ potassium phosphate buffer ( $\mathrm{pH} 7.0$ ), $10 \mathrm{mM} \mathrm{H}_{2} \mathrm{O}_{2}$, and $200 \mu \mathrm{l}$ of enzyme extract. The amount of CAT required to decompose $1.0 \mu \mathrm{M}$ of $\mathrm{H}_{2} \mathrm{O}_{2}$ per min was defined as one unit of CAT activity.

Ascorbate peroxidase (APX, EC 1.11.1.11) activity was determined according to Nakano and Asada (1981) by monitoring the rate of ascorbate oxidation at $290 \mathrm{~nm}$ (extinction coefficient $2.8 \mathrm{mM}^{-1} \mathrm{~cm}^{-1}$ ). The assay mixture contained $50 \mathrm{mM}$ potassium phosphate buffer ( $\mathrm{pH}$ 7.0), $0.5 \mathrm{mM}$ AsA (vitamin C), $0.1 \mathrm{mM} \mathrm{H}_{2} \mathrm{O}_{2}$, and $200 \mu \mathrm{l}$ of enzyme extract. One unit of enzyme activity was defined as the amount of enzyme oxidizing $1 \mu$ mol(AsA) per mg protein and per min. The activity was expressed as unit per $\mathrm{mg}$ of protein.

Peroxidase (POD, EC 1.11.1.7) activity was measured using guaiacol as a substrate (Nickel and Cunningham 1969). The increase in absorbance at $470 \mathrm{~nm}$ (extinction coefficient $26.6 \mathrm{mM}^{-1} \mathrm{~cm}^{-1}$ ) due to the guaiacol oxidation was recorded for $3 \mathrm{~min}$. The reaction mixture contained $25 \mathrm{mM}$ phosphate buffer ( $\mathrm{pH}$ 7.0), $0.05 \%$ guaiacol, $1.0 \mathrm{mM} \mathrm{H}_{2} \mathrm{O}_{2}$, and $0.1 \mathrm{ml}$ of enzyme extract. One unit of POD activity indicates the amount of enzyme that catalyses the oxidation of $1.0 \mu \mathrm{M}$ of guaiacol in $1 \mathrm{~min}$.

Measurement of lipid peroxidation and $\mathrm{H}_{2} \mathrm{O}_{2}$ production: Lipid peroxidation was determined by measuring the amount of produced MDA by the thiobarbituric acid reaction as described by Jiang and Zhang (2001). The crude extract was mixed with the same volume of a $0.5 \%$ (w/v) thiobarbituric acid solution containing $20 \%(\mathrm{w} / \mathrm{v})$ tricholoroacetic acid. The homogenate was heated at $95^{\circ} \mathrm{C}$ for $30 \mathrm{~min}$ and then immediately cooled. The mixture was centrifuged at $3,000 \times \mathrm{g}$ for $10 \mathrm{~min}$ and the absorbance of the supernatant was monitored at 532 and $600 \mathrm{~nm}$ (U-2000, Hitachi Instruments, Tokyo, Japan). After subtracting the nonspecific absorbance $(600 \mathrm{~nm})$, the MDA content was determined by its molar extinction coefficient $\left(155 \mathrm{Mm}^{-1} \mathrm{~cm}^{-1}\right)$ and expressed as $\mathrm{nmol} \mathrm{g}(\mathrm{FM})$.

$\mathrm{H}_{2} \mathrm{O}_{2}$ content was determined according to Velikova et al. (2000). Frozen leaf sample (1 g) was ground in an ice bath with $5 \mathrm{ml} 0.1 \%(\mathrm{w} / \mathrm{v})$ trichloroacetic acid. The homogenate was centrifuged at $12,000 \times g$ for $15 \mathrm{~min}$ and $0.5 \mathrm{ml}$ of the supernatant was added to $0.5 \mathrm{ml}$ of $10 \mathrm{mM}$ potassium phosphate buffer ( $\mathrm{pH} 7)$. The absorbance of the supernatant was measured at $390 \mathrm{~nm}$ using a spectrophotometer (U-2000, Hitachi Instruments, Tokyo, Japan). $\mathrm{H}_{2} \mathrm{O}_{2}$ content was determined using the extinction coefficient $0.28 \mu \mathrm{M}^{-1} \mathrm{~cm}^{-1}$ and the amount expressed as $\mu \mathrm{mol} \mathrm{g}^{-1}(\mathrm{FM})$.

Starch analysis: Fresh leaf sample (the youngest fullyexpanded leaves) was homogenized in $80 \%$ ethanol. After extraction, the concentration of starch was measured by the method of Hedge and Hofreiter (1962). The absorbance was measured at $630 \mathrm{~nm}$ using a spectrophotometer (U-2000, Hitachi Instruments, Tokyo, Japan). Glucose was used as standard solution. Starch content was expressed per FM.

Electrolyte leakage (EL) was used to assess membrane permeability. EL was measured using an electrical conductivity meter (CC-501; Elmetron, Zabrze, Poland). Five leaf discs were taken from the youngest fullyexpanded leaf on one randomly chosen plant per replicate sample (pot). After three washes with distilled water to remove surface contamination, five leaf discs were then placed in test tube containing $10 \mathrm{ml}$ of distilled water. These samples were incubated for $24 \mathrm{~h}$ on a shaker at room temperature. The electrical conductivity (EC) of the solution (EC1) was read after incubation. The same samples were then placed in an autoclave at $120^{\circ} \mathrm{C}$ for 20 min and the second EC reading (EC2) was taken after cooling the solution to room temperature. EL was then calculated as EC1/EC2, and expressed as a percentage (Lutts et al. 1995).

Relative water content (RWC) of leaves was determined following the method suggested by Barrs and Weatherley (1962). Leaf discs weighed (FM) and washed three times with double distilled water were placed into a $10-\mathrm{ml}$ conical flask. Leaf discs were immersed in $10 \mathrm{ml}$ of distilled water for $4 \mathrm{~h}$ at $4^{\circ} \mathrm{C}$ in dark. Turgid mass (TM) of leaf discs was then measured and samples were dried in 
hot air oven at $70^{\circ} \mathrm{C}$ until constant mass (DM) was achieved. RWC was estimated using the following equation: $\mathrm{RWC}(\%)=[(\mathrm{FM}-\mathrm{DM}) /(\mathrm{TM}-\mathrm{DM})] \times 100$.

Chlorophyll (Chl) was determined using fully expanded leaves. A fresh leaf sample of $0.5 \mathrm{~g}$ was ground and extracted with $5 \mathrm{ml}$ of $80 \%(\mathrm{v} / \mathrm{v})$ acetone in the dark. The slurry was filtered, centrifuged at 5,000 $\times g$ for $10 \mathrm{~min}$ and absorbance was determined at 645 and $663 \mathrm{~nm}$, for Chl $a$ and Chl $b$ concentrations, respectively, using a spectrophotometer (U-2000, Hitachi Instruments, Tokyo, Japan). Concentrations of Chl $a, \mathrm{Chl} b$, and $\mathrm{Chl}_{\text {tot }}$ were determined according to Lichtenthaler and Wellburn (1983).

Proline accumulation (Pro) was determined according to the method described by Bates et al. (1973). Seedlings $(0.5 \mathrm{~g}$ of fresh shoot material) were homogenized in $10 \mathrm{ml}$ of $3 \%(\mathrm{v} / \mathrm{v})$ aqueous sulphosalicylic acid and filtered through a Whatman No. 2 filter paper. The filtrate $(2 \mathrm{ml})$ was then mixed with $2 \mathrm{ml}$ of acid-ninhydrin reagent and $2 \mathrm{ml}$ of glacial acetic acid in a test tube and the mixture was placed in a water bath for $1 \mathrm{~h}$ at $100^{\circ} \mathrm{C}$. The reaction mixture was extracted with $4 \mathrm{ml}$ of toluene, and the chromophore-containing toluene fraction was aspirated, cooled to room temperature, and its absorbance measured at $520 \mathrm{~nm}$ using a spectrophotometer (U-2000, Hitachi Instruments, Tokyo, Japan). Appropriate Pro standards (Sigma Chemical Co., St. Louis, MO, USA) were included in order to calculate the concentration of Pro in each shoot tissue sample.

Chl fluorescence was measured in the dark- and lightadapted leaves between 9:00-11:00 h, with a portable fluorometer (PAM-2500, Walz, Effeltrich, Germany). After $30 \mathrm{~min}$ of dark adaptation, $\mathrm{F}_{\mathrm{v}} / \mathrm{F}_{\mathrm{m}}$ was calculated as $\left(F_{m}-F_{0}\right) / F_{m}$, where $F_{m}$ [induced by a short pulse $(0.6 \mathrm{~s})$ of saturating light of $3,450 \mu \mathrm{mol}\left(\right.$ photon) $\mathrm{m}^{-2} \mathrm{~s}^{-1}$ ] and $\mathrm{F}_{0}$ were the maximal and minimal fluorescence, respectively (Genty et al. 1989). After 4 min of illumination with continuous red, nonsaturating actinic light $[447 \mu \mathrm{mol}($ photon) $\mathrm{m}^{-2} \mathrm{~s}^{-1}$ ] and saturating pulses every $25 \mathrm{~s}$, the maximum $\left(F_{m}{ }^{\prime}\right)$ and the steady state $\left(F_{s}\right)$ fluorescence signals were measured in the light-adapted leaves. Then, the actinic

\section{Results and discussion}

Growth parameters: The plants grown in the soil supplemented with $75 \mathrm{mM}$ of $\mathrm{NaCl}$ showed a significant decrease in the values of all the growth biomarkers (LN, SL, TPFM, TPDM) in comparison with control plants. The spray of Spd or SNP alone or SNP + Spd to the foliage of stress-free plants significantly increased all the growth markers. Plant LN of with Spd or SNP alone or $\mathrm{SNP}+\mathrm{Spd}$ treatments increased compared with $\mathrm{NaCl}$ alone (S) treatment. SL of S-treated Bakraii seedlings decreased with increasing salt concentration but different spray with Spd or SNP alone or Spd + SNP improved the light was turned off and the far-red pulse was applied to obtain the minimal fluorescence after the PSI excitation $\left(\mathrm{F}_{0}{ }^{\prime}\right)$. Photochemical quenching coefficient $\left(\mathrm{q}_{\mathrm{P}}\right)$ was calculated as $\left(F_{m}{ }^{\prime}-F_{s}\right) /\left(F_{m}{ }^{\prime}-F_{0}{ }^{\prime}\right)$ (van Kooten and Snel 1990). Nonphotochemical quenching, NPQ, which is proportional to the rate constant of the thermal energy dissipation, was estimated as $\left(\mathrm{F}_{\mathrm{m}}-\mathrm{F}_{\mathrm{m}}{ }^{\prime}\right) / \mathrm{F}_{\mathrm{m}}{ }^{\prime}$ (Bilger et al. 2001).

Gas-exchange parameters, such as net photosynthetic rate $\left(P_{\mathrm{N}}\right)$, intercellular $\mathrm{CO}_{2}$ concentration $\left(C_{\mathrm{i}}\right)$, transpiration $(E)$, and stomatal conductance $\left(g_{\mathrm{s}}\right)$, were measured between 9:00-11:00 $\mathrm{h}$ at the end of the experiment using a portable photosynthetic system (LI-6200, LI-COR Inc., Lincoln, NE, USA). Top fully expanded leaf was clamped to the leaf chamber and the observations were recorded when $\mathrm{RH}$ and atmospheric $\mathrm{CO}_{2}$ concentration $\left(C_{\mathrm{a}}\right)$ reached a stable value. PAR, air temperature, relative humidity, and $\mathrm{CO}_{2}$ concentration inside the sensor head were set at $1,000 \pm 100 \mu \mathrm{mol}$ (photon) $\mathrm{m}^{-2} \mathrm{~s}^{-1}, 28 \pm 2^{\circ} \mathrm{C}, 60 \%$, and $380-400 \mu \mathrm{mol} \mathrm{m}^{-1}$, respectively, when measuring $P_{\mathrm{N}}$.

Soluble sugar: The concentration of soluble sugars was measured by the anthrone method (Palma et al. 2009). Approximately $0.15 \mathrm{~g}$ of fresh assimilating leaf sample was sheared into fine pieces and incubated in $15 \mathrm{ml}$ of distilled water in a water bath at $100^{\circ} \mathrm{C}$ for $1 \mathrm{~h}$. This extraction solution $(0.05 \mathrm{ml})$ was added to $0.15 \mathrm{ml}$ of distilled water and mixed with $0.05 \mathrm{ml}$ of anthrone ethyl acetate. To develop colour, $0.5 \mathrm{ml}$ of concentrated sulphuric acid was added to the mixture, which was then immediately boiled for $1 \mathrm{~min}$. The absorbance of the solution was measured at $630 \mathrm{~nm}(U-2000$, Hitachi Instruments, Tokyo, Japan) and the concentration of soluble sugars determined using a standard curve prepared from a sucrose standard.

Statistical analysis: All data were presented as means \pm SD of 4 replicate seedlings. Statistical analyses were performed by one-way analysis of variance (ANOVA) based on completely randomized design using the $S A S$ program version 9.1 (SAS Inc., Cary, NC, USA). Differences between treatments were separated by the least significant differences (LSD) test at $P<0.05$.

growth of the plants. The maximum increase of SL was recorded for the plants treated by Spd + SNP, while the minimum SL was recorded for the seedlings at $\mathrm{S}(75 \mathrm{mM}$ $\mathrm{NaCl})$ treatments. There was a significant decrease of TPFM and TPDM in plants treated with $75 \mathrm{mM} \mathrm{NaCl}$. When plants treated with Spd or SNP alone or Spd + SNP under $\mathrm{S}$ stress, the TPFM and TPDM increased compared with $\mathrm{S}$ treatment (Table 1).

Growth inhibition by salinity has been attributed to the disturbance in water and osmotic potential, toxicity of excessive $\mathrm{Na}^{+}$and $\mathrm{Cl}^{-}$, disturbance in the accumulation of 
nutrients, disruption in the structure and the activity of the enzymes, damage in cell organelles and plasma membrane, disturbances in photosynthesis, respiration, and protein synthesis (Feng et al. 2002, Munns 2005). It is interesting to observe that co-application of SNP and Spd proved to be more effective in the improvement of growth parameters under salt stress; perhaps, it could be due to their synergistic or additive effects. It has been suggested that the main role of PAs is to maintain a cation-anion balance during long-term salinity (Santa-Cruz et al. 1997). Hence, the use of exogenous PAs supported the physiological activity by increasing growth (Parvin et al. 2014). NO acted on the phospholipid bilayer, improved the fluidness of the membrane, cell enlargement, and plant growth (Leshem and Wills 1998). Foliar applied NO acts as a growth regulator and is able to modulate the plant metabolism and the production of metabolites involved in stress tolerance (Takahama and Oniki 1997). In this regard, Huaifu et al. (2007) suggested that SNP-mediated increase in plant growth could be related to SNP-induced enhancement in the $P_{\mathrm{N}}$ under salt stress. Exogenous Put, Spd and Spm pre-treatment to Arabidopsis seedlings incresed NO concentration (Wimalasekera et al. 2011), which reduces the harmfulness of the reactive oxygen species (ROS). These results are in agreement with present findings that combination of SNP (as a NO donor) and Spd have beneficial effects on growth.

Physiological and biochemical parameters: Leaf $\mathrm{Na}^{+}$ and $\mathrm{Cl}^{-}$concentrations were significantly elevated with $\mathrm{S}$ treatment. The foliar application of Spd or SNP alone or $\mathrm{Spd}+\mathrm{SNP}$ resulted in the significant reduction of the $\mathrm{Na}^{+}$ and $\mathrm{Cl}^{-}$contents in the leaves. Salinity reduced $\mathrm{K}^{+}, \mathrm{Ca}^{2+}$, and $\mathrm{Mg}^{2+}$ concentrations in leaves. The lowest $\mathrm{K}^{+}, \mathrm{Ca}^{2+}$, and $\mathrm{Mg}^{2+}$ contents were related to non-Spd or SNP treate
Bakraii seedlings under $\mathrm{S}$ treatment. Leaf $\mathrm{Ca}^{2+}, \mathrm{Mg}^{2+}$, and $\mathrm{K}^{+}$significantly increased by the exogenous application of Spd or SNP alone or Spd + SNP (Table 2). The ratio of $\mathrm{Na}^{+} / \mathrm{K}^{+}$has been proposed as an indicator of salinity tolerance. This index increased considerably after the $\mathrm{S}$ treatment with respect to control. Spd or SNP alone or Spd + SNP applied together with $75 \mathrm{mM} \mathrm{NaCl}$ decreased this ratio above the value obtained in the plants treated exclusively with $\mathrm{S}$ treatment (Table 2).

The presence of $\mathrm{NaCl}$ in the water used for irrigation changes the nutritional balance of plants, leading to high ratios of $\mathrm{Na}^{+} / \mathrm{Ca}^{+2}, \mathrm{Na}^{+} / \mathrm{Mg}^{+2}$, and $\mathrm{Na}^{+} / \mathrm{K}^{+}$that can cause an inhibition of the growth in citrus. The main saline ions $\mathrm{Na}^{+}$and $\mathrm{Cl}^{-}$can influence the nutrient absorption through competitive interactions or by influencing the ion selectivity of membranes (Behboudian et al. 1986). This result was in agreement with previous studies that exogenous Spd could alleviate salt-induced ion toxicity and nutrition imbalance by reducing the $\mathrm{Na}^{+}$influx and $\mathrm{K}^{+}$, $\mathrm{Ca}^{2+}$, and $\mathrm{Mg}^{2+}$ efflux (Roy et al. 2005). Due to their polycationic nature, PAs, especially Spd, contribute to maintain cellular cation-anion balance, and may act as a signaling regulator responsible for inward rectification of rectifying $\mathrm{K}^{+}$channels and certain $\mathrm{Ca}^{2+}$-permeable channels (Yamaguchi et al. 2007). Consequently, exogenous Spd pre-treatment might promote salinity tolerance by regulating the ion metabolism in Bakraii. Increased $\mathrm{K}^{+}$ and $\mathrm{Ca}^{2+}$ contents due to application of SNP may be explained based on the property of $\mathrm{K}^{+}$and $\mathrm{Ca}^{2+}$ to replace $\mathrm{Na}^{+}$, as a result of mutual competition between the two ions for a transport site on a carrier protein, and maintain a high capacity of restricting salt uptake and transport under salt stress, and inhibition of membrane-associated carrier protein thereby maintaining its integrity (Khan et al. 2010, López-Carrión et al 2008).

Table 1. Growth characteristics and biomass of Iranian mandarin Bakraii seedlings treated with Spd, SNP, and Spd + SNP under saline conditions. Each value was mean $\pm \mathrm{SD}(n=4)$. Mean values followed by the same letters within a column are not significantly different at $p<0.05$. C - control; LN - leaf number; $\mathrm{S}-75 \mathrm{mM} \mathrm{NaCl}$; SL - shoot length; SNP - sodium nitroprusside; Spd - spermidine; TPDM - total plant dry mass; TPFDM - total plant fresh mass; CV - coefficient of variation.

\begin{tabular}{lllll}
\hline Treatment & LN & TPDM $[\mathrm{g}]$ & TPFM $[\mathrm{g}]$ & SL $[\mathrm{cm}]$ \\
\hline C & $38.0 \pm 2.94^{\mathrm{c}}$ & $13.8 \pm 0.29^{\mathrm{c}}$ & $46.8 \pm 1.82^{\mathrm{c}}$ & $34.7 \pm 0.85^{\mathrm{c}}$ \\
Spd & $44.0 \pm 3.65^{\mathrm{ab}}$ & $15.8 \pm 0.36^{\mathrm{b}}$ & $48.9 \pm 0.72^{\mathrm{ab}}$ & $38.2 \pm 0.82^{\mathrm{ab}}$ \\
SNP & $41.0 \pm 1.84^{\mathrm{ab}}$ & $15.0 \pm 0.52^{\mathrm{b}}$ & $47.2 \pm 0.85^{\mathrm{bc}}$ & $37.9 \pm 1.64^{\mathrm{b}}$ \\
Spd + SNP & $46.0 \pm 3.65^{\mathrm{a}}$ & $16.6 \pm 0.73^{\mathrm{a}}$ & $49.8 \pm 0.83^{\mathrm{a}}$ & $40.4 \pm 2.58^{\mathrm{a}}$ \\
S & $15.0 \pm 2.94^{\mathrm{f}}$ & $05.4 \pm 0.88^{\mathrm{g}}$ & $21.2 \pm 1.82^{\mathrm{f}}$ & $19.0 \pm 1.68^{\mathrm{f}}$ \\
S + Spd & $23.7 \pm 1.72^{\mathrm{e}}$ & $09.8 \pm 0.67^{\mathrm{e}}$ & $35.3 \pm 0.85^{\mathrm{e}}$ & $25.0 \pm 0.36^{\mathrm{e}}$ \\
S + SNP & $25.0 \pm 2.58^{\mathrm{de}}$ & $08.9 \pm 0.34^{\mathrm{f}}$ & $33.9 \pm 0.92^{\mathrm{e}}$ & $25.8 \pm 0.67^{\mathrm{e}}$ \\
S + Spd + SNP & $28.0 \pm 1.82^{\mathrm{d}}$ & $11.9 \pm 0.26^{\mathrm{d}}$ & $39.1 \pm 1.73^{\mathrm{d}}$ & $28.3 \pm 2.75^{\mathrm{d}}$ \\
ANOVA & & & & \\
Treatment & $* * *$ & $* *$ & $* *$ & $* * *$ \\
CV [\%] & 8.4 & 4.5 & 3.2 & 5.2 \\
\hline
\end{tabular}


Table 2. Leaf $\mathrm{Cl}^{-}, \mathrm{Na}^{+}, \mathrm{K}^{+}, \mathrm{Ca}^{2+}, \mathrm{Mg}^{2+}$, and $\mathrm{Na}^{+} / \mathrm{K}^{+}$ratio in Iranian mandarin Bakraii seedlings treated with Spd, SNP, and Spd $+\mathrm{SNP}$ under saline conditions. Each value was mean $\pm \mathrm{SD}(n=4)$. Mean values followed by the same letters within a column are not significantly different at $p<0.05$. C - control; $\mathrm{S}-75 \mathrm{mM} \mathrm{NaCl}$; SNP - sodium nitroprusside; $\mathrm{Spd}$ - spermidine; CV - coefficient of variation.

\begin{tabular}{|c|c|c|c|c|c|c|}
\hline Treatment & $\mathrm{Cl}^{-}[\mathrm{c} \%]$ & $\mathrm{Na}^{+}[\%]$ & $\mathrm{K}^{+}[\mathrm{C} /]$ & $\mathrm{Ca}^{2+}[\mathrm{c} /]$ & $\mathrm{Mg}^{2+}[\%]$ & $\mathrm{Na}^{+} / \mathrm{K}^{+}$ratio \\
\hline $\mathrm{C}$ & $0.76 \pm 1.24^{\mathrm{d}}$ & $0.18 \pm 0.05^{\mathrm{d}}$ & $2.0 \pm 0.16^{b}$ & $2.20 \pm 0.03^{b c}$ & $1.7 \pm 0.51^{\mathrm{b}}$ & $0.09 \pm 0.01^{\mathrm{d}}$ \\
\hline Spd & $0.54 \pm 1.28^{\mathrm{d}}$ & $0.13 \pm 0.04^{\mathrm{d}}$ & $2.5 \pm 0.08^{\mathrm{ab}}$ & $2.60 \pm 0.02^{\mathrm{ab}}$ & $1.8 \pm 0.26^{\mathrm{ab}}$ & $0.05 \pm 0.03^{\mathrm{d}}$ \\
\hline SNP & $0.62 \pm 1.22^{\mathrm{d}}$ & $0.15 \pm 0.03^{\mathrm{d}}$ & $2.3 \pm 0.06^{\mathrm{ab}}$ & $2.40 \pm 0.04^{\mathrm{ab}}$ & $1.8 \pm 0.36^{\mathrm{ab}}$ & $0.07 \pm 0.02^{\mathrm{d}}$ \\
\hline Spd + SNP & $0.43 \pm 1.24^{\mathrm{d}}$ & $0.11 \pm 0.05^{\mathrm{d}}$ & $2.6 \pm 0.09^{\mathrm{a}}$ & $2.90 \pm 0.03^{\mathrm{a}}$ & $2.2 \pm 0.25^{\mathrm{a}}$ & $0.04 \pm 0.04^{\mathrm{d}}$ \\
\hline $\mathrm{S}$ & $4.30 \pm 1.24^{\mathrm{a}}$ & $2.40 \pm 0.47^{\mathrm{a}}$ & $1.2 \pm 0.16^{\mathrm{c}}$ & $1.20 \pm 0.36^{\mathrm{d}}$ & $0.7 \pm 0.29^{c}$ & $2.00 \pm 0.36^{\mathrm{a}}$ \\
\hline $\mathrm{S}+\mathrm{Spd}$ & $2.80 \pm 1.24^{\mathrm{b}}$ & $1.30 \pm 0.29^{b}$ & $2.6 \pm 0.16^{\mathrm{ab}}$ & $1.80 \pm 0.47^{\mathrm{c}}$ & $1.4 \pm 0.36^{\mathrm{b}}$ & $0.52 \pm 0.21^{b c}$ \\
\hline $\mathrm{S}+\mathrm{SNP}$ & $3.20 \pm 1.28^{b}$ & $1.35 \pm 0.51^{\mathrm{b}}$ & $2.3 \pm 0.08^{\mathrm{ab}}$ & $1.82 \pm 0.51^{\mathrm{c}}$ & $1.5 \pm 0.55^{\mathrm{b}}$ & $0.64 \pm 0.12^{\mathrm{b}}$ \\
\hline $\mathrm{S}+\mathrm{Spd}+\mathrm{SNP}$ & $2.20 \pm 1.22^{\mathrm{c}}$ & $0.92 \pm 0.43^{\mathrm{c}}$ & $2.8 \pm 0.06^{\mathrm{a}}$ & $2.10 \pm 0.44^{b c}$ & $1.5 \pm 0.18^{\mathrm{b}}$ & $0.34 \pm 0.29^{c}$ \\
\hline \multicolumn{7}{|l|}{$A N O V A$} \\
\hline Treatment & $* *$ & $* *$ & $*$ & $* *$ & $* *$ & $* *$ \\
\hline CV [\%] & 16.8 & 18.2 & 18.9 & 17.9 & 21.5 & 22.4 \\
\hline
\end{tabular}

Salt stress significantly increased EL and Pro with maximum increase observed in the plants grown with $75 \mathrm{mM} \mathrm{NaCl}$. The application of Spd or SNP alone or Spd + SNP significantly decreased EL and Pro in leaf discs, with the largest decrease in EL and Pro measured when $0.50 \mathrm{mM} \mathrm{Spd}+\mathrm{SNP}$ were applied. RWC was reduced by $\mathrm{S}$ treatment, but foliar application of SNP alone or Spd + SNP improved this factor (Table 3).

In the present study, membrane permeability was determined by measuring EL. An increase in EL indicates elevated leakiness of ions due to a loss of membrane integrity. This is an inherent feature of plants which are exposed to stresses such as salinity (Sharma et al. 2011). This study showed that foliar Spd or SNP alone or Spd + SNP application reduced the ion leakage (measured as electrolytes) in S-stressed Bakraii plants indicating that Spd and SNP treatment facilitated the maintenance of membrane functions under stress conditions. According to the results, it was found that the combined use of Spd + SNP is more effective than their individual use for reducing the effects of salt stress. It is clear that both Spd and NO crosstalk to stimulate the stress-inducing factors in the plant under stress conditions. Maintaining integrity of cellular membranes under salt stress is considered an integral part of salinity-tolerance mechanism (Stevens et al. 2006). This is probably due to the fact that PAs causes increases in the activities of antioxidant enzymes which, in turn, protect plants against the generation of ROS and membrane injury, or may result in the synthesis of other substances which have a protective effect on plants growing under salt stress (Upchurch 2008). In addition to their properties as free radical scavengers, PAs were also reported to stabilize biological membrane by direct binding to membrane phospholipids in stress conditions (Todorova et al. 2007). In the present study, lower EL with SNP may originate from salinity induced constraints on water availability and ion uptake, thus resulting in the reduction of root pressure-driven xylem transport rates of
Table 3. Leaf characteristics of Iranian mandarin Bakraii seedlings treated with Spd, SNP, and Spd + SNP under saline conditions. Each value was mean $\pm \mathrm{SD}(n=4)$. Mean values followed by the same letters within a column are not significantly different at $p<0.05$. C - control; EL - electrolyte leakage; Pro - proline content; RWC - relative water content; S - $75 \mathrm{mM}$ $\mathrm{NaCl}$; SNP - sodium nitroprusside; Spd - spermidine; CV coefficient of variation.

\begin{tabular}{llll}
\hline Treatment & EL [\%] & RWC [\%] & $\begin{array}{l}\text { Pro } \\
{\left[\mu \mathrm{mol} \mathrm{g}{ }^{-1}(\mathrm{FM})\right]}\end{array}$ \\
\hline C & $12.8 \pm 1.84^{\mathrm{d}}$ & $86.2 \pm 1.03^{\mathrm{a}}$ & $22.0 \pm 2.54^{\mathrm{d}}$ \\
Spd & $10.3 \pm 1.33^{\mathrm{de}}$ & $88.3 \pm 0.82^{\mathrm{a}}$ & $19.8 \pm 2.98^{\mathrm{d}}$ \\
SNP & $11.3 \pm 1.63^{\mathrm{de}}$ & $87.4 \pm 1.62^{\mathrm{a}}$ & $20.2 \pm 4.12^{\mathrm{d}}$ \\
Spd + SNP & $09.4 \pm 1.31^{\mathrm{e}}$ & $89.2 \pm 0.88^{\mathrm{a}}$ & $18.8 \pm 1.83^{\mathrm{d}}$ \\
S & $41.4 \pm 1.23^{\mathrm{a}}$ & $42.3 \pm 3.77^{\mathrm{d}}$ & $72.0 \pm 3.69^{\mathrm{a}}$ \\
S + Spd & $27.4 \pm 1.84^{\mathrm{bc}}$ & $59.2 \pm 1.63^{\mathrm{c}}$ & $40.2 \pm 4.94^{\mathrm{bc}}$ \\
S + SNP & $29.9 \pm 1.33^{\mathrm{b}}$ & $57.2 \pm 1.82^{\mathrm{c}}$ & $45.2 \pm 2.58^{\mathrm{b}}$ \\
$\mathrm{S}+$ Spd + SNP & $25.2 \pm 1.29^{\mathrm{c}}$ & $65.4 \pm 1.62^{\mathrm{b}}$ & $34.8 \pm 4.16^{\mathrm{c}}$ \\
ANOVA & & & \\
Treatment & $* * *$ & $* *$ & $*$ \\
CV [\%] & 9.1 & 10.8 & 18.3 \\
\hline
\end{tabular}

water and mineral nutrients to the shoot. Reports suggested a reduction in electrolyte leakage may be explained on the basis of SNP-facilitated maintenance of membrane functions through induction of antioxidant mechanisms and elevated ion uptake, thereby protecting the plants against the oxidative damage (Liu et al. 2014). Huaifu et al. (2007) reported that exogenous NO reduced the membrane permeability and membrane lipid peroxidation, and prevented the electrolyte leakage.

The RWC is a useful measure of the physiological water status of plants. RWC in leaves is known as an alternative measure of plant water status, reflecting the metabolic activity in tissues (González and González-Vilar 2001). RWC reduction indicated a loss of turgor that resulted in limited water availability for the cell extension 
process (Katerji et al. 1997) that may be caused by lower water availability under stress conditions (Shalhevet 1993), and/or root systems which are not able to compensate for water lost by transpiration through a reduction of the absorbing surface (Gadallah 2000). The protective effect of PAs on RWC under $\mathrm{NaCl}$ treatments has been reported earlier (Sheokand et al. 2008). GarcíaMata and Lamattina (2001) reported that SNP-treated water-stressed wheat seedlings tended to retain more water than that of water-stressed seedlings.

Results showed that under salinity stress, the Pro concentration of Bakraii leaves increased. Pro has multiple functions, such as osmotic pressure regulation, protection of membrane integrity, stabilization of enzymes/proteins, maintaining appropriate $\mathrm{NADP}^{+} / \mathrm{NADPH}$ ratios and scavenger of free radicals (Hare and Cress 1997). In this study, Spd or SNP alone or Spd + SNP application reduced salt-induced Pro accumulation which suggested that saltimposed stress might be partially alleviated without requiring the accumulation of Pro to high concentrations. This appears to be supported by Jiménez-Bremont et al. (2006) who reported that exogenous PAs decreased Pro accumulation in salinity-exposed Phaseolus vulgaris L. The Pro degradation seems to be beneficial in the response to stress, given that the degradation of Pro to glutamate generates reducing equivalents that support mitochondrial oxidative phosphorylation (Hare and Cress 1997). Furthermore, the proline dehydrogenase activity is capable of consuming $\mathrm{O}_{2}^{--}$(Hare and Cress 1997), and perhaps could reduce the oxidizing power of the cell and in turn possibly generate ROS (Rosales et al. 2007, LópezCarrión et al. 2008). On the other hand, SNP appears to be capable of mitigating damage associated with salinity stress by reducing oxidative stress and inducing Pro degradation, mechanisms that permit the plant to adapt under these conditions (López-Carrión et al. 2008).

The protein, soluble sugar and starch content were significantly influenced by the salt stress and Spd or SNP alone or Spd + SNP application improved these parameters (Table 4).

In general, under salt stress, starch content decreases (Chaves et al. 2009), which is in accordance with the present study. Photosynthesis is one of the phenomena inhibited under the stress resulting in a reduction of starch and soluble carbohydrates within the leaves (Demetriou et al. 2007, Ruiz et al. 1997). Another implication of the starch and sucrose depletion promoted by the different levels of salinity is that leaves could change from source to sink under these adverse conditions (Arbona et al. 2005). In plants, PAs seem to play an important role via interaction with many anionic molecules, such as DNA, RNA, proteins, and membrane lipids, due to the polycationic nature of PAs (Bouchereau et al. 1999). Liu et al (2014) reported that foliage application of SNP accelerated accumulation of proteins and soluble sugars under salt stress. Moreover, free radicals such as $\mathrm{H}_{2} \mathrm{O}_{2}$ produced under salt stress conjugate to proteins and lead to the destruction of their structure. Therefore, the impact of Spd + SNP might be due to either preventing the production of free radicals or free radicals scavenging mechanisms and subsequently protecting the proteins (Peltzer et al. 2002, Sheokand et al. 2008).

The activity of SOD, CAT, POD, and APX increased with salinity and application of Spd or SNP alone or Spd + SNP had an additive effect on the activities of these enzymes. In the present study, we observed higher activities of SOD, CAT, POD, and APX content in the plants exposed to $\mathrm{NaCl}$ stress with $\mathrm{Spd}+\mathrm{SNP}$ treatments (Table 5). Lipid peroxidation is one of the first indications of oxidative damage, and production of MDA can be used as an indicator of oxidative stress. Exposure to $\mathrm{NaCl}$ stress increased MDA compared with control leaves. However, Spd or SNP alone or Spd + SNP significantly reduced the contents of MDA under $\mathrm{NaCl}$ stress. $\mathrm{H}_{2} \mathrm{O}_{2}$ content also illustrated the same tendency (Table 6).

Salt stress, like other abiotic stresses, can lead to oxidative stress through the increase in ROS, which could potentiate the accumulation of MDA, an indicator of saltinduced oxidative damage to membranes (Hernández and Almansa 2002). CAT is an important antioxidant enzyme that catabolizes hydrogen peroxide (Larsen et al. 1988). $\mathrm{H}_{2} \mathrm{O}_{2}$ is one of the major and most stable ROS and its high concentration leads to oxidative stress through an increase of lipid peroxidation and modification of membrane permeability (Upchurch 2008) and Spd or SNP alone or SNP + Spd alleviate oxidative injury in plants by acting as direct free radical scavengers (Beligni et al. 2002, Wu et al. 2011). Salinity has been reported to increase SOD activity in cucumber plants (Huaifu et al. 2007) and in citrus (Almansa et al. 2002). Salt stress accelerated the $\mathrm{O}_{2}{ }^{-}$ production and induced a great increase in the SOD activity. Spd or SNP alone or Spd + SNP under $\mathrm{NaCl}$ stress improved the SOD activity in leaves, which demonstrated that Spd or SNP alleviated the injury to citrus seedlings under $\mathrm{NaCl}$ stress. This finding confirms the report of Parida and Das (2005) in regard to the mutual relationship between higher antioxidant activity and salinity tolerance. Our results showed the additive effects of Spd + SNP for reduction of ROS and induction of synthesis of antioxidant enzymes under salinity stress. Wimalasekera et al. (2011) observed that the PAs, Spd and Spm, greatly increased NO release in Arabidopsis thaliana seedlings. It is well documented that PAs counteract oxidative damage in plants by acting as direct free radical scavengers or binding to antioxidant enzyme molecules to scavenge free radical (Bors et al. 1989). Previous finding proposed that transgenic tobacco may significantly induce the expression of antioxidant enzymes by elevating the PAs content (Wi et al. 2006), resulting in tolerance to different abiotic stresses. It is evident that PAs exhibit their antioxidant 
Table 4. Chl $a, \mathrm{Chl} b, \mathrm{Chl}_{\mathrm{tot}}, \mathrm{Chl} a / b$, protein, starch, and soluble sugar (SSU) in leaves of Iranian mandarin Bakraii seedlings treated with Spd, SNP, and Spd + SNP under saline conditions. Each value was mean $\pm \operatorname{SD}(n=4)$. Mean values followed by the same letters within a column are not significantly different at $p<0.05$. C - control; Chl tot - total chlorophyll concentration; $\mathrm{S}-75 \mathrm{mM} \mathrm{NaCl}$; SSU soluble sugar; SNP - sodium nitroprusside; Spd - spermidine; CV - coefficient of variation.

\begin{tabular}{|c|c|c|c|c|c|c|c|}
\hline $\begin{array}{l}\text { Treatment } \\
\mathrm{s}\end{array}$ & $\begin{array}{l}\text { Chl } a \\
{\left[\mathrm{mg} \mathrm{g}^{-1}(\mathrm{FM})\right]}\end{array}$ & $\begin{array}{l}\text { Chl } b \\
{\left[\mathrm{mg} \mathrm{g}^{-1}(\mathrm{FM})\right]}\end{array}$ & $\begin{array}{l}\text { Chl }_{\text {tot }} \\
{\left[\mathrm{mg} \mathrm{g}^{-1}(\mathrm{FM})\right]}\end{array}$ & $\begin{array}{l}\mathrm{Chl} a / b \\
{\left[\mathrm{mg} \mathrm{g}^{-1}(\mathrm{FM})\right]}\end{array}$ & $\begin{array}{l}\text { Protein } \\
{\left[\mathrm{mg} \mathrm{g}^{-1}(\mathrm{FM})\right]}\end{array}$ & $\begin{array}{l}\text { Starch } \\
{\left[\mathrm{mg} \mathrm{g}^{-1}(\mathrm{FM})\right]}\end{array}$ & $\begin{array}{l}\text { SSU } \\
{\left[\mathrm{mg} \mathrm{g}^{-1}(\mathrm{FM})\right]}\end{array}$ \\
\hline $\mathrm{C}$ & $0.64 \pm 0.07^{b}$ & $0.30 \pm 0.08^{a}$ & $0.94 \pm 0.04^{b}$ & $2.14 \pm 0.12^{\mathrm{ab}}$ & $2.34 \pm 0.47^{\mathrm{ab}}$ & $75.6 \pm 4.6^{\mathrm{b}}$ & $26.0 \pm 3.65^{b c}$ \\
\hline Spd & $0.64 \pm 0.01^{b}$ & $0.31 \pm 0.06^{\mathrm{a}}$ & $0.95 \pm 0.02^{\mathrm{b}}$ & $2.06 \pm 0.05^{\mathrm{b}}$ & $2.57 \pm 0.42^{\mathrm{a}}$ & $78.2 \pm 5.9^{\mathrm{ab}}$ & $27.8 \pm 1.82^{b}$ \\
\hline SNP & $0.67 \pm 0.02^{b}$ & $0.31 \pm 0.04^{\mathrm{a}}$ & $0.98 \pm 0.03^{\mathrm{ab}}$ & $2.17 \pm 0.09^{\mathrm{ab}}$ & $2.43 \pm 0.33^{\mathrm{ab}}$ & $77.6 \pm 6.2^{b}$ & $26.7 \pm 2.58^{b c}$ \\
\hline Spd + SNP & $0.76 \pm 0.04^{\mathrm{a}}$ & $0.33 \pm 0.05^{\mathrm{a}}$ & $1.09 \pm 0.03^{\mathrm{a}}$ & $2.30 \pm 0.08^{\mathrm{a}}$ & $2.66 \pm 0.17^{\mathrm{a}}$ & $86.2 \pm 5.7^{\mathrm{a}}$ & $34.7 \pm 3.37^{\mathrm{a}}$ \\
\hline $\mathrm{S}^{\mathrm{T}}$ & $0.22 \pm 0.01^{\mathrm{d}}$ & $0.18 \pm 0.02^{\mathrm{c}}$ & $0.40 \pm 0.05^{\mathrm{d}}$ & $1.22 \pm 0.03^{\mathrm{d}}$ & $1.05 \pm 0.39^{\mathrm{d}}$ & $22.7 \pm 3.6^{\mathrm{e}}$ & $14.2 \pm 3.08^{\mathrm{e}}$ \\
\hline $\mathrm{S}+\mathrm{Spd}$ & $0.37 \pm 0.06^{\mathrm{c}}$ & $0.23 \pm 0.04^{b}$ & $0.60 \pm 0.02^{\mathrm{c}}$ & $1.62 \pm 0.04^{\mathrm{c}}$ & $1.61 \pm 0.36^{\mathrm{c}}$ & $48.3 \pm 1.8^{\mathrm{cd}}$ & $19.1 \pm 2.58^{\mathrm{d}}$ \\
\hline $\mathrm{S}+\mathrm{SNP}$ & $0.37 \pm 0.06^{\mathrm{c}}$ & $0.24 \pm 0.03^{b}$ & $0.61 \pm 0.04^{\mathrm{c}}$ & $1.55 \pm 0.05^{\mathrm{c}}$ & $1.62 \pm 0.46^{\mathrm{c}}$ & $42.3 \pm 9.6^{\mathrm{d}}$ & $19.9 \pm 4.16^{\mathrm{d}}$ \\
\hline $\mathrm{S}+\mathrm{Spd}+\mathrm{SNP}$ & $0.42 \pm 0.02^{c}$ & $0.24 \pm 0.02^{\mathrm{b}}$ & $0.66 \pm 0.03^{c}$ & $1.76 \pm 0.07^{\mathrm{c}}$ & $1.89 \pm 0.18^{\mathrm{bc}}$ & $54.3 \pm 3.4^{\mathrm{c}}$ & $22.3 \pm 3.65^{\mathrm{cd}}$ \\
\hline \multicolumn{8}{|l|}{$A N O V A$} \\
\hline Treatment & $* *$ & $* *$ & $* *$ & $* *$ & $* * *$ & $* * *$ & $*$ \\
\hline CV [\%] & 9.9 & 12.2 & 10.4 & 7.9 & 18.3 & 9.4 & 13.4 \\
\hline
\end{tabular}

Table 5. Antioxidant enzyme activities in leaves of Iranian mandarin Bakraii seedlings treated with Spd, SNP, and Spd + SNP under saline conditions. Each value was mean $\pm \mathrm{SD}(n=5)$. Mean values followed by the same letters within a column are not significantly different at $p<0.05$. APX - ascorbate peroxidase; $\mathrm{C}$ - control; CAT - catalase; POD - peroxidase; $\mathrm{S}-75 \mathrm{mM} \mathrm{NaCl}$; $\mathrm{SNP}-\mathrm{sodium}$ nitroprusside; SOD - superoxide dismutase; Spd - spermidine; $\mathrm{CV}$ - coefficient of variation.

\begin{tabular}{|c|c|c|c|c|}
\hline Treatment & $\begin{array}{l}\text { CAT } \\
\text { [unit } \mathrm{mg}^{-1} \text { protein] }\end{array}$ & $\begin{array}{l}\text { SOD } \\
\text { [unit } \mathrm{mg}^{-1} \text { protein] }\end{array}$ & $\begin{array}{l}\text { APX } \\
\text { [unit } \mathrm{mg}^{-1} \text { protein] }\end{array}$ & $\begin{array}{l}\text { POD } \\
\text { [unit } \mathrm{mg}^{-1} \text { protein] }\end{array}$ \\
\hline $\begin{array}{l}\text { C } \\
\text { Spd } \\
\text { SNP } \\
\text { Spd + SNP } \\
\text { S } \\
\text { S + Spd } \\
\text { S + SNP } \\
\text { S + Spd + SNP }\end{array}$ & $\begin{array}{l}0.08 \pm 0.01^{\mathrm{e}} \\
0.16 \pm 0.09^{\mathrm{de}} \\
0.14 \pm 0.04^{\mathrm{de}} \\
0.20 \pm 0.03^{\mathrm{d}} \\
0.44 \pm 0.03^{\mathrm{c}} \\
0.62 \pm 0.08^{\mathrm{b}} \\
0.57 \pm 0.06^{\mathrm{b}} \\
0.82 \pm 0.08^{\mathrm{a}}\end{array}$ & $\begin{array}{l}12 \pm 2.64^{\mathrm{f}} \\
18 \pm 5.94^{\mathrm{de}} \\
15 \pm 4.39^{\text {ef }} \\
21 \pm 3.36^{\mathrm{d}} \\
34 \pm 3.65^{\mathrm{c}} \\
44 \pm 3.36^{\mathrm{ab}} \\
41 \pm 2.58^{\mathrm{b}} \\
48 \pm 1.82^{\mathrm{a}}\end{array}$ & $\begin{array}{l}1.10 \pm 3.36^{\mathrm{f}} \\
1.32 \pm 1.82^{\mathrm{ef}} \\
1.36 \pm 2.58^{\mathrm{def}} \\
1.53 \pm 4.39^{\mathrm{cde}} \\
1.74 \pm 1.82^{\mathrm{bcd}} \\
1.96 \pm 2.82^{\mathrm{ab}} \\
1.88 \pm 1.63^{\mathrm{abc}} \\
2.15 \pm 2.45^{\mathrm{a}}\end{array}$ & $\begin{array}{l}0.20 \pm 0.08^{\mathrm{d}} \\
0.30 \pm 0.18^{\mathrm{d}} \\
0.28 \pm 0.02^{\mathrm{d}} \\
0.40 \pm 0.20^{\mathrm{cd}} \\
0.64 \pm 0.16^{\mathrm{bc}} \\
0.83 \pm 0.25^{\mathrm{ab}} \\
0.82 \pm 0.23^{\mathrm{ab}} \\
0.94 \pm 0.18^{\mathrm{a}}\end{array}$ \\
\hline $\begin{array}{l}\text { ANOVA } \\
\text { Treatment } \\
\text { CV [\%] }\end{array}$ & $\begin{array}{l}* * \\
16.5\end{array}$ & $\begin{array}{l}* * \\
12.6\end{array}$ & $\begin{array}{l}* * \\
17.3\end{array}$ & $\begin{array}{l}* \\
15.6\end{array}$ \\
\hline
\end{tabular}

effect by inducing the expression of genes encoding antioxidant enzymes. Therefore, PAs may function not only as scavengers of ROS, but also as activators of the expressions of genes encoding antioxidant enzymes (Parvin et al. 2014). NO disproportioned $\mathrm{O}_{2}{ }^{-}-$to $\mathrm{H}_{2} \mathrm{O}_{2}$, so the content of $\mathrm{H}_{2} \mathrm{O}_{2}$ increased with the improved SOD activity. Under $\mathrm{NaCl}$ stress, $\mathrm{H}_{2} \mathrm{O}_{2}$ was eliminated by some enzymes, such as POD, CAT, APX, and their activity increased. Exogenous SNP could markedly improve the SOD, POD, CAT, APX activities, thereby improving the ability of scavenging free radicals and alleviating the injury, and decreasing membrane permeability and MDA content (Beligni et al. 2002, Verma and Mishra 2005). Because of the existence of an unpaired electron within the molecule, NO can react directly with some ROS, such as $\mathrm{H}_{2} \mathrm{O}_{2}$, superoxide anion $\left(\mathrm{O}_{2}{ }^{-}\right)$, and the hydroxyl radical $\left({ }^{\circ} \mathrm{OH}\right)$. Reaction of $\mathrm{NO}$ with $\mathrm{O}_{2}{ }^{-}$produces peroxynitrite
$\left(\mathrm{ONOO}^{\circ}\right)$, which is a toxic product. However, ONOO' can be protonated and decomposed to a nitrate anion and a proton or it can react with hydrogen peroxide to yield a nitrite anion and oxygen (Laspina 2005).

Photosynthetic parameters: $P_{\mathrm{N}}, E, g_{\mathrm{s}}$, and $C_{\mathrm{i}}$ were significantly reduced by the treatment of $\mathrm{NaCl}$ in comparison with the control plants. The application of Spd or SNP alone or SNP + Spd to the plants significantly increased the value of $P_{\mathrm{N}}, E, g_{\mathrm{s}}$, and $C_{\mathrm{i}}$ compared with the $\mathrm{NaCl}$-treated plants (Table 7). Chl tot was significantly affected by salinity and Spd or SNP alone or SNP + Spd pretreatment. There was a significant decrease in $\mathrm{Chl} a$ and $\mathrm{Chl} b$ content after the treatment with $75 \mathrm{mM} \mathrm{NaCl}$. When treated with Spd or SNP alone or SNP + Spd in the presence of $\mathrm{NaCl}$, the $\mathrm{Chl}_{\text {tot }}$ content increased compared with the sole $\mathrm{NaCl}$ treatment (Table 4). The fluorescence 
Table 6. MDA and $\mathrm{H}_{2} \mathrm{O}_{2}$ in Iranian mandarin Bakraii seedlings treated with Spd, SNP, and Spd + SNP under saline conditions. Each value was mean $\pm \mathrm{SD}(n=4)$. Mean values followed by the same letters within a column are not significantly different at $p<0.05$. C - control; $\mathrm{H}_{2} \mathrm{O}_{2}-$ hydrogen peroxide; MDA malondialdehyde; $\mathrm{S}-75 \mathrm{mM} \mathrm{NaCl} ; \mathrm{SNP}$ - sodium nitroprusside; $\mathrm{Spd}$ - spermidine; CV - coefficient of variation.

\begin{tabular}{lll}
\hline Treatment & $\begin{array}{l}\mathrm{MDA} \\
{\left[\mathrm{nmol} \mathrm{g}{ }^{-1}(\mathrm{FM})\right]}\end{array}$ & $\begin{array}{l}\mathrm{H}_{2} \mathrm{O}_{2} \\
{\left[\mu \mathrm{mol} \mathrm{g}{ }^{-1}(\mathrm{FM})\right]}\end{array}$ \\
\hline $\mathrm{C}$ & $15.5 \pm 4.14^{\mathrm{d}}$ & $20.6 \pm 2.05^{\mathrm{d}}$ \\
Spd & $11.2 \pm 2.62^{\mathrm{de}}$ & $21.0 \pm 1.82^{\mathrm{d}}$ \\
SNP & $12.3 \pm 1.26^{\mathrm{de}}$ & $20.0 \pm 3.65^{\mathrm{d}}$ \\
Spd + SNP & $11.0 \pm 3.26^{\mathrm{e}}$ & $20.0 \pm 4.08^{\mathrm{d}}$ \\
$\mathrm{S}$ & $42.8 \pm 2.45^{\mathrm{a}}$ & $38.5 \pm 3.03^{\mathrm{a}}$ \\
$\mathrm{S}+$ Spd & $28.4 \pm 3.44^{\mathrm{bc}}$ & $27.0 \pm 2.58^{\mathrm{bc}}$ \\
$\mathrm{S}+$ SNP & $31.3 \pm 1.62^{\mathrm{b}}$ & $30.7 \pm 2.98^{\mathrm{b}}$ \\
$\mathrm{S}+$ Spd + SNP & $25.5 \pm 1.26^{\mathrm{c}}$ & $26.0 \pm 3.65^{\mathrm{c}}$ \\
ANOVA & & \\
Treatment & $* *$ & $* *$ \\
CV [\%] & 13.4 & 12.1 \\
\hline
\end{tabular}

parameters were used as a nondestructive method to determine the functional state of the photosynthetic machinery. The fluorescence parameters were significantly affected by salt stress and Spd or SNP alone or Spd + SNP concentration (Table 8 ). Salinity stress decreased $F_{v} / F_{m}$ and $F_{v}$ in the leaves of Bakraii seedlings. These results indicate harmful effects of $\mathrm{NaCl}$ on metabolic processes ultimately resulting in reduced efficiency of PSII. The $\mathrm{F}_{\mathrm{v}} / \mathrm{F}_{\mathrm{m}}$ in the dark-adapted state significantly decreased due to the salt-induced increase of $\mathrm{F}_{0}$ and the marked decline of $F_{m}$. Salt stress significantly decreased $\mathrm{q}_{\mathrm{P}}$ in the lightadapted state but markedly elevated NPQ. The pretreatment by Spd or SNP alone or Spd + SNP to the NaCltreated plants completely recovered the loss of fluorescence parameters (Table 8).

A decrease in leaf $\mathrm{Chl}$ content has been described in citrus rootstocks irrigated with high $\mathrm{NaCl}$ concentration (García-Sánchez et al. 2002, Koshbakht and Asgharei 2015a). This loss of Chl content could be associated with accumulation of $\mathrm{Cl}^{-}$and $\mathrm{Na}^{+}$in the leaves (Anjum 2007). The decrease in leaf $\mathrm{Chl}$ concentration could occur due to changes in the lipid protein ratio of pigment-protein complexes (Rao and Rao 1981), increased chlorophyllase activity and degradation (Singh and Dubey 1995), and an inhibition in the synthesis of photosynthetic pigments (García-Sánchez et al. 2002). Photosynthetic pigments present in the photosystems are believed to be damaged by stress factors resulting in a reduced light-absorbing efficiency of both photosystems (PSI and PSII) and hence a reduced photosynthetic capacity (Zhang et al. 2011). This is attributed to the rate of $\mathrm{CO}_{2}$ assimilation which is generally reduced in response to salinity and this reduction is partially due to reduced $g_{\mathrm{s}}$ and due to the direct effects of $\mathrm{NaCl}$ on the photosynthetic apparatus independently of stomatal closure, which has also been reported for several plant species, both halophytes and nonhalophytes (Torrecillas et al. 1995). In the present study, salinityinduced reductions in Chl, $P_{N}, g_{\mathrm{s}}$, and $C_{\mathrm{i}}$ were alleviated by exogenous PAs and SNP, in accordance with a similar experiment, implying that exogenous PAs (Anjum 2009) and SNP (Huaifa et al. 2007) alleviates the damage of photosynthetic apparatus under salinity conditions. The combination of Spd + SNP was better than Spd or SNP alone. The $F_{v} / F_{m}$ is correlated with the efficiency of leaf photosynthesis. A decline in this ratio provides an indicator of photoinhibitory damage caused by the incident photon flux density when plants are subjected to a wide range of environmental stresses (Björkman and Demming 1987). The salt-induced increase of $F_{0}$ and the marked decline of $F_{m}$ imply the inhibitory effects on PSII reaction center although the elevated NPQ may dissipate excess excitation energy (Wang et al. 2007). The reduction of $F_{v}$ along with an increase in $F_{0}$ is considered to be characteristic for inhibition of the acceptor side of PSII (Setlík et al. 1990). The reduction in $\mathrm{F}_{\mathrm{v}} / \mathrm{F}_{\mathrm{m}}$ and $\mathrm{q}_{\mathrm{p}}$ were correlated with an increase in NPQ suggesting that salt treatment induced dissipation of damaging excessive energy. This energy could be dissipated at antennae through heat emission although other mechanisms are also involved in energy dissipation, e.g., related to a transmembrane $\mathrm{H}^{+}$ gradient generated by ATPase activity and uncoupling of electron transport, which may lead to oxidative stress (Maxwell and Johnson 2000). Earlier studies have indicated that salt stress reduced $P_{\mathrm{N}}$ and $g_{\mathrm{s}}$ in the leaves of many crops (Syeed et al. 2011). A decline in photosynthetic capacity under salt stress is often associated with the generation of ROS (Noreen et al. 2010). Salt stress hinders $P_{\mathrm{N}}$ at multiple levels, such as pigments, stomatal functioning, gaseous exchange, structure and function of thylakoid membrane, electron transport, and enzyme activities, by preventing the oxidative stress reduction mechanisms and cellular metabolism of plants (Sudhir and Murthy 2004). Excessive salt concentrations might cause the closure of stomata, thereby decreasing the partial $\mathrm{CO}_{2}$ pressure and $C_{\mathrm{i}}$ and consequently resulting in a decreased $P_{\mathrm{N}}$ (Bethke and Drew 1992). It is well documented that PAs are involved in protection against different environmental stresses in plants (Bouchereau et al. 1999). There have been several reports establishing that PAs, especially the thylakoid-bound PAs, participate in the regulation of structure and function of photosynthetic apparatus under environmental conditions, such as UV-B radiation (Lütz et al. 2005), low temperature (Sfakianaki et al. 2006), and salinity (Demetriou et al. 2007). PAs exert positive effects on photosynthetic efficiency under stress conditions due to their acid-neutralizing and antioxidant properties, as well as their membrane- and cell wall-stabilizing activity (Mapelli et al. 2008). PAs with a high net positive charge can stabilize PSII proteins such as D1 and D2 under photoinhibition conditions. PAs binding to membrane 
Table 7. Gas-exchange characteristics in leaves of Iranian mandarin Bakraii seedlings treated with Spd, SNP, and Spd + SNP under saline conditions. Each value was mean $\pm \mathrm{SD}(n=4)$. Mean values followed by the same letters within a column are not significantly different at $p<0.05$. C - control; $C_{\mathrm{i}}-$ intercellular $\mathrm{CO}_{2}$ concentration; $E$ - transpiration rate; $g_{\mathrm{s}}-$ stomatal conductance; $P_{\mathrm{N}}-$ net photosynthetic rate; $\mathrm{S}-75 \mathrm{mM} \mathrm{NaCl}$; $\mathrm{SNP}$ - sodium nitroprusside; $\mathrm{Spd}$ - spermidine; $\mathrm{CV}$ - coefficient of variation.

\begin{tabular}{lllll}
\hline Treatment & $\begin{array}{l}P_{\mathrm{N}} \\
{\left[\mu \mathrm{mol}\left(\mathrm{CO}_{2}\right) \mathrm{m}^{-2} \mathrm{~s}^{-1}\right]}\end{array}$ & $\begin{array}{l}g_{\mathrm{s}} \\
{\left[\mathrm{mmol}\left(\mathrm{H}_{2} \mathrm{O}\right) \mathrm{m}^{-2} \mathrm{~s}^{-1}\right]}\end{array}$ & $\begin{array}{l}E \\
{\left[\mathrm{mmol}\left(\mathrm{H}_{2} \mathrm{O}\right) \mathrm{m}^{-2} \mathrm{~s}^{-1}\right]}\end{array}$ & $\begin{array}{l}C_{\mathrm{i}} \\
\left.[\mu \mathrm{mol} \mathrm{mol})^{-1}\right]\end{array}$ \\
\hline $\mathrm{C}$ & $7.9 \pm 1.82^{\mathrm{b}}$ & $0.36 \pm 0.08^{\mathrm{b}}$ & $2.4 \pm 0.36^{\mathrm{cb}}$ & $350 \pm 18.2^{\mathrm{c}}$ \\
Spd & $8.8 \pm 1.80^{\mathrm{ab}}$ & $0.42 \pm 0.03^{\mathrm{ab}}$ & $2.9 \pm 0.18^{\mathrm{ab}}$ & $450 \pm 09.1^{\mathrm{a}}$ \\
$\mathrm{SNP}$ & $8.4 \pm 1.61^{\mathrm{ab}}$ & $0.39 \pm 0.02^{\mathrm{b}}$ & $2.8 \pm 0.29^{\mathrm{b}}$ & $410 \pm 09.6^{\mathrm{b}}$ \\
Spd + SNP & $9.8 \pm 0.82^{\mathrm{a}}$ & $0.47 \pm 0.07^{\mathrm{a}}$ & $3.4 \pm 0.46^{\mathrm{a}}$ & $470 \pm 29.4^{\mathrm{a}}$ \\
$\mathrm{S}$ & $2.1 \pm 0.96^{\mathrm{e}}$ & $0.12 \pm 0.01^{\mathrm{e}}$ & $0.9 \pm 0.18^{\mathrm{e}}$ & $146 \pm 06.4^{\mathrm{f}}$ \\
$\mathrm{S}+$ Spd & $4.0 \pm 0.56^{\mathrm{d}}$ & $0.23 \pm 0.04^{\mathrm{cd}}$ & $1.7 \pm 0.33^{\mathrm{d}}$ & $265 \pm 09.4^{\mathrm{ed}}$ \\
$\mathrm{S}+$ SNP & $3.9 \pm 0.86^{\mathrm{d}}$ & $0.20 \pm 0.02^{\mathrm{d}}$ & $1.5 \pm 0.56^{\mathrm{d}}$ & $250 \pm 14.8^{\mathrm{e}}$ \\
$\mathrm{S}+$ Spd + SNP & $5.8 \pm 0.46^{\mathrm{c}}$ & $0.28 \pm 0.03^{\mathrm{c}}$ & $1.9 \pm 0.19^{\mathrm{cd}}$ & $274 \pm 05.9^{\mathrm{d}}$ \\
ANOVA & & & & \\
Treatment & $* * *$ & $* *$ & $* *$ & $*$ \\
CV [\%] & 19.7 & 15.1 & 15.8 & 8.5 \\
\hline
\end{tabular}

Table 8. Fluorescence parameters in leaves of Iranian mandarin Bakraii seedlings treated with Spd, SNP, and Spd + SNP under saline conditions. Each value was mean $\pm \mathrm{SD}(n=4)$. Mean values followed by the same letters within a column are not significantly different at $p<0.05 . \mathrm{C}$ - control; $\mathrm{F}_{\mathrm{m}}-$ maximal fluorescence yield of the dark-adapted state; $\mathrm{F}_{0}$ - minimal fluorescence yield of the dark-adapted state; $F_{v}$ - variable fluorescence; $F_{v} / F_{m}$ - maximum photochemical efficiency of PSII; NPQ - nonphotochemical quenching; $\mathrm{q}_{\mathrm{P}}$ - photochemical quenching; $\mathrm{S}-75 \mathrm{mM} \mathrm{NaCl}$; Spd - spermidine; $\mathrm{CV}$ - coefficient of variation.

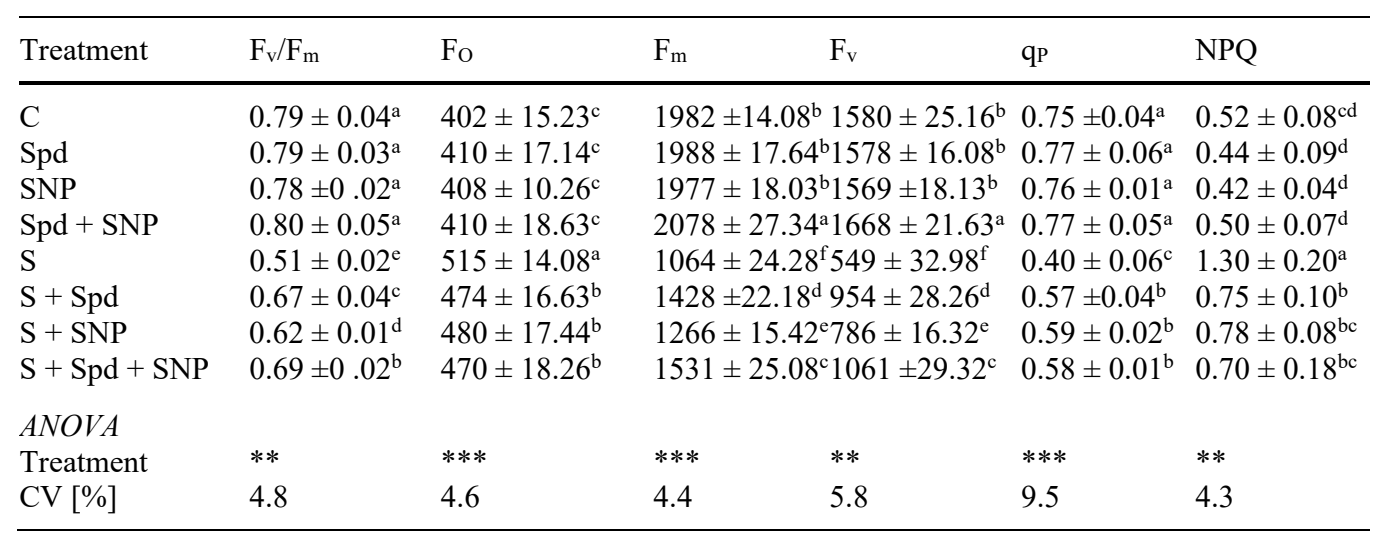

proteins may stabilize the protein structure during stress and consequently preserve photosynthetic activity (Hamdani et al. 2011). Exogenous SNP reduced the decrease of photosynthesis in cells of leaves because of salt stress, and improved Chl, $P_{\mathrm{N}}, E, g_{\mathrm{s}}, C_{\mathrm{i}}, \mathrm{F}_{\mathrm{v}} / \mathrm{F}_{\mathrm{m}}$, and $\mathrm{q}_{\mathrm{p}}$ but decreased NPQ. Higher $g_{\mathrm{s}}$ values showed higher transduction ability of the substrate in relation to net $P_{\mathrm{N}}$, for assimilating more photosynthetic production. Increase of $E$ enhanced the power of absorption and transportation for water, which was beneficial to the increase of photosynthesis and salt tolerance (Liu et al. 2014). Huaifa et al. (2007) reported that exogenous NO might enhance the salt resistance of cucumber seedlings by improving the photosynthesis in leaves. The results of Wimalasekera et al. (2011), showed that NO may be a link between PAmediated stress responses filling a gap between many known physiological effects of PAs and amelioration of stresses. Therefore, SNP (as NO donor) along with Spd showed synergistic effect under in salinity stress in citrus, which could alleviate the salinity stress and help in improving the photosynthesis in citrus.

Conclusion: In summary, this investigation study revealed that salt stress had inhibitory effects on growth, gas exchange, and Chl fluorescence of Bakraii seedlings. Spd and SNP played important roles in alleviation $\mathrm{NaCl}$ toxicity in the citrus seedlings. Intractive effects of Spd + SNP were more effective compared to the seprate applications of Spd + SNP. Spd, SNP, and Spd + SNP significantly ameliorated the adverse effects of $\mathrm{NaCl}$ stress by enhanced activities of antioxidative enzymes, and promoted photosynthesis. 


\section{References}

Aebi H.: Catalase in vitro. - Methods Enzymol. 105: 121-126, 1984.

Alcázar R., Altabella T., Marco F. et al.: Polyamines: molecules withregulatory functions in plant abiotic stress tolerance. Planta 231: 1237-1249, 2010.

Almansa M.S., Hernandez J.A., Jimenez A. et al.: Effect of salt stress on the superoxide dismutase activity in leaves of Citrus limonum in different rootstock-scion combinations. - Biol. Plantarum 45: 545-549, 2002.

Anjum M.A.: Effect of exogenously applied spermidine on growth and physiology of citrus rootstock Troyer citrange under saline conditions. - Turk. J. Agric. For. 35: 43-55, 2009.

Anjum M.A.: Effect of $\mathrm{NaCl}$ concentration in irrigation water on growth and polyamine metabolism in two citrus rootstocks with different levels of salinity tolerance. - Acta Physiol. Plant 30: 43-52, 2007.

Arasimowicz M., Floryszak-Wieczorek J.: Nitric oxide as a bioactive signaling molecule in plant stress responses. - Plant Sci. 172: 876-887, 2007.

Arbona V., Aurelio J., Domingo J.: Carbohydrate depletion in roots and leaves of salt-stressed potted Citrus clementina L. Plant Growth Regul. 46: 153-160, 2005.

Barrs H.D., Weatherley P.E.: A re-examination of the relative turgidity technique for estimating water deficits in leaves. Aust. J. Biol. Sci. 15: 413-428, 1962.

Bates L., Waldren P.P., Teare J.D.: Rapid determination of the free proline of water stress studies. - Plant Soil 39: 205-207, 1973.

Beauchamp C., Fridovich I.: Superoxide dismutase: improved assays and an assay applicable to acrylamide gels. - Anal. Biochem. 44: 276-287, 1971.

Behboudian M.H., Törökfalvy E., Walker R.R.: Effects of Salinity on ionic content, water relations and gas exchanges parameters in some citrus scion-rootstock combinations. - Sci. Hortic.-Amsterdam 28: 105-116, 1986.

Beligni M.V., Fath A., Bethke P.C. et al.: Nitric oxide acts as an antioxidant and delays programmed cell death in barley aleurone layers. - Plant Physiol. 129: 1642-1650, 2002.

Bethke P.C., Drew M.C.: Stomatal and nonstomatal components to inhibition of photosynthesis in leaves of Capsicum annum during progressive exposure to $\mathrm{NaCl}$ salinity. - Plant Physiol. 99: 219-226, 1992.

Bilger W., Johnsen T., Schreiber U.: UV-excited chlorophyll fluorescence as a tool for the assessment of UV-protection by the epidermis of plants. - J. Exp. Bot. 52: 2007-2014, 2001.

Björkman O., Demming B.: Photon yield of oxygen evolution and chlorophyll fluorescence characteristics at $77 \mathrm{~K}$ among vascular plants of diverse origin. - Planta 170: 489-504, 1987.

Blokhina O., Virolainen E., Fagerstedt K.V.: Antioxidants, oxidative damage and oxygen deprivation stress: a review. Ann. Bot.-London 91:179-194, 2003.

Bors W., Langebartels C., Michel C. et al.: Polyamines as radical scavengers and protectants against ozone damage. - Phytochemistry 28: 1589-1595, 1989.

Bouchereau A., Aziz A., Larher F. et al.: Polyamines and environmental challenges: recent development. - Plant Sci. 140: 103-125, 1999.

Bradford M.N.: A rapid and sensitive method for the quantitation of microgram quantities of protein utilizing the principles of protein-dye binding. - Anal Biochem. 72: 248-254, 1976.

Chaves M.M., Flexas J., Pinheiro C.: Photosynthesis under drought and salt stress: regulation mechanisms from whole plant to cell. - Ann. Bot.-London 103: 551-560, 2009.

Demetriou G., Neonaki C., Navakoudis E. et al.: Salt stress impact on the molecular structure and function of the photosynthetic apparatus-the protective role of polyamines. - BBABioenergetics 1767: 272-280, 2007.

Dhindsa R.S., Plumb-Dhindsa P., Thorpe T.A.: Leaf senescence: correlated with increased levels of membrane permeability and lipid peroxidation, and decreased levels of superoxide dismutase and catalase. - J. Exp. Bot. 32: 93-101, 1981.

Feng G., Zhang F.S., Li X.L. et al.: Improved tolerance of maize plants to salt stress by arbuscular mycorrhiza is related to higher accumulation of soluble sugars in roots. - Mycorrhiza 12: $185-190,2002$.

Gadallah M.A.A.: Effects of indole-3-acetic acid and zinc on the growth, osmotic potential and soluble carbon and nitrogen components of soybean plants growing under water deficit. $-\mathrm{J}$. Arid. Environ. 44: 451-467, 2000.

Galston A.W., Kaur-Sawhney R., Altabella T. et al.: Plant polyamines in reproductive activity and response to a biotic stress. - Bot. Acta 110: 197-207, 1997.

García-Mata C., Lamattina L.: Nitric oxide induces stomatal closure and enhances the adaptive plant responses against drought stress. - Plant Physiol. 126: 1196-1204, 2001.

García-Sánchez F., Jifon J.L., Carvajal M. et al.: Gas exchange, chlorophylle and nutrient content in relation to $\mathrm{Na}$ and $\mathrm{Cl}$ accumulation in sunburst mandarin grafted on different rootstock. - Plant Sci. 162: 705-712, 2002.

Genty B., Briantais J.M., Baker N.B.: The relationship between the quantum yield of photosynthetic electrontransport and quenching of chlorophyll fluorescence. - Biochim. Biophys. Acta 990: 87-92, 1989.

González L., González-Vilar M.: Determination of relative water content. - In: Reigosa M.J. (ed.): Handbook of Plant Ecophysiology Techniques. Pp. 207-212. Kluwer Academic, Dordrecht 2001.

Hamdani S., Gauthier A., Msilini N. et al:: Positive charges of polyamines protect PSII in isolated thylakoid membranes during photoinhibitory conditions. - Plant Cell Physiol. 52: 866-873, 2011.

Hare P.D., Cress W.A.: Metabolic implications of stress-induced proline accumulation in plants. - Plant Growth Regul. 21: 79 $102,1997$.

Hedge J.E., Hofreiter B.T.: Estimation of starch by anthrone reagent. - In: Whistler R.L., Be-Miller J.N. (ed.): Methods in Carbohydrate Chemistry. Pp. 420. Academic Press, New York 1962.

Hernández J.A., Almansa M.S.: Short-term effects of salt stress on antioxidant systems and leaf water relations of pea leaves. Physiol. Plantarum 115: 251-257, 2002.

Hernández J.A., Campillo A., Jimenez A. et al.: Response of antioxidant systems and leaf water relations to $\mathrm{NaCl}$ stress in pea plants. - New Phytol. 141: 241-251, 1999.

Huaifu F., Shirong G., Yansheng J. et al.: Effects of exogenous nitric oxide on growth, active oxygen species metabolism, and photosynthetic characteristics in cucumber seedlings $\mathrm{NaCl}$ stress. - Front. Agric. China 1: 308-314, 2007

Jiang M.Y., Zhang J.H.: Effect of abscisic acid on active oxygen species, antioxidative defence system and oxidative damage in leaves of maize seedlings. - Plant Cell. Physiol. 42: 1265-1273, 2001. 
Jiménez-Bremont J.F., Becerra Flora A., Hernández-Lucero E. et $a l .:$ Proline accumulation in two bean cultivars under salt stress and the effect of polyamines and ornithine. - Biol. Plantarum 50:763-766, 2006.

Katerji N., van Hoorn J.W., Hamdy A. et al.: Osmotic adjustment of sugarbeets in response to soil salinity and its influence on stomatal conductance, growth and yield. - Agr. Water Manage. 34: 57-69, 1997.

Khan N.M., Siddiqui M.H., Mohammad F. et al.: Calcium chloride and gibberellic acid protect linseed (Linum usitatissimum L.) from $\mathrm{NaCl}$ stress by inducing antioxidative defence system and osmoprotectant accumulation. - Acta Physiol. Plant. 32: 121-132, 2010.

Khayyat M., Tehranifar T., Davarynejad G.H.: Effects of $\mathrm{NaCl}$ salinity on some leaf nutrient concentrations, non-photochemical quenching and the efficiency of the PSII photochemistry of two Iranian pomegranate varieties under greenhouse and field conditions: Preliminary results. - J. Plant Nutr. 39: 1752-1765, 2016.

Khoshbakht D., Ghorbani A., Baninasab B. et al.: Effects of supplementary potassium nitrate on growth and gas-exchange characteristics of salt-stressed citrus seedlings. - Photosynthetica 52: 589-596, 2014.

Khoshbakht D., Asgharei M.R.: Influence of foliar-applied salicylic acid on growth, gas-exchange characteristics, and chlorophyll fluorescence in citrus under saline conditions. Photosynthetica 53: 410-418, 2015a.

Khoshbakht D., Ramin A.A., Baninasab B.: Effects of sodium chloride stress on gas exchange, chlorophyll content and nutrient concentrations of nine citrus rootstocks. - Photosynthetica 53: 241-249, 2015 b.

Kusano T., Berberich T., Tateda C. et al.: Polyamines: essential factors for growth and survival. - Planta 228: 367-381, 2008.

Lamattina L., García-Mata C., Graziano M. et al.: Nitric oxide: the versatility of an extensive signal molecule. - Annu. Rev. Plant Biol. 54: 109-136, 2003.

Larsen M.H., Davis T.D., Evans R.P.: Modulation of protein expression in uniconazole treated soybean in relation to heat stress. - Proc. Plant Growth Reg. Soc. Am. 15: 177-182, 1988.

Laspina N.V., Groppa M.D., Tomaro M.L., Benavides M.P.: Nitric oxide protects sunflower leaves against $\mathrm{Cd}$-induced oxidative stress. - Plant Sci. 169: 323-330, 2005.

Leshem Y.Y., Wills R.B.H., Ku V.V.V.: Evidence for the function of the free radical gas-nitric oxide (NO) as an endogenous maturation and senescence regulating factor in higher plants. - Plant Physiol. Bioch. 36: 825-833, 1998.

Lichtenthaler H.K., Wellburn W.R.: Determination of total carotenoids and chlorophylls $a$ and $b$ of leaf extracts in different solvents. - Biochem. Soc. T. 11: 591-592, 1983.

Liu S., Dong Y., Xu L. et al.: Effects of foliar applications of nitric oxide and salicylic acid on salt-induced changes in photosynthesis and antioxidative metabolism of cotton seedlings. - Plant Growth Regul. 73: 67-68, 2014.

Lopatin A.N., Makhina E.N., Nichols C.G.: Potassium channel block by cytoplasmic polyamines as the mechanism of intrinsic rectification. - Nature 372: 366-369, 1994.

López-Carrión A.I., Castellano R., Rosales M.A. et al.: Role of nitric oxide under saline stress: implications on proline metabolism. - Biol. Plantarum 52: 587-591, 2008.

Lutts S., Kinet J.M., Bouharmont J.: Changes in plant response to $\mathrm{NaCl}$ during development of rice (Oryza sativa L.) varieties differing in salinity resistance. - J. Exp. Bot. 46: 1843-1852, 1995.
Lütz C., Navakoudis E., Seidlitz H.K. et al.: Simulated solar irradiation with enhanced UV-B adjust plastid- and thylakoidassociated polyamine changes for UV-B protection. - BBABioenergetics 1710: 24-33, 2005.

Mapelli S., Brambilla I., Radyukina N. et al:: Free and bound polyamines changes in different plants as a consequence of UV-B light irradiation. - Gen. Appl. Plant Physiol. 34: 55-66, 2008 .

Maxwell K., Johnson G.N.: Chlorophyll fluorescence - a practical guide. - J. Exp. Bot. 51: 659-668, 2000.

Mittler R.: Oxidative stress, antioxidants and stress tolerance. Trends Plant Sci. 7: 405-410, 2002.

Moya J.L., Primo-Millo E., Talon M.: Morphological factors determining salt tolerance in citrus seedlings: the shoot to root ratio modulates passive root uptake of chloride ions and their accumulation in leaves. - Plant Cell Environ. 22: 1425-1433, 1999.

Munns R., Tester M.: Mechanisms of salinity tolerance. - Annu. Rev. Plant Biol. 59: 651-681, 2008.

Munns R.: Genes and salt tolerance: bringing them together. New Phytol. 167: 645-663, 2005.

Nakano Y., Asada K.: Hydrogen peroxide is scavenged by ascorbate-specific peroxidase in spinach chloroplasts. - Plant Cell. Physiol. 22: 867-880, 1981

Nickel R.S., Cunningham B.A.: Improved peroxidase assay method using leuco-2,3,6-trichloroindophenol and application to comparative measurements of peroxidase catalysis. - Anal. Biochem. 27: 292-299, 1969.

Noreen Z., Ashraf M., Akram N.A.: Salt-induced regulation of some key antioxidant enzymes and physio-biochemical phenomena in five diverse cultivars of turnip (Brassica rapa L.). - J. Agron. Crop Sci. 196: 273-285, 2010.

Palma F., Lluch C., Iribarne C. et al.: Combined effect of salicylic acid and salinity on some antioxidant activities, oxidative stress and metabolite accumulation in Phaseolus vulgaris. - Plant Growth Regul. 58: 307-316, 2009.

Parida A.K., Das A.B.: Salt tolerance and salinity effects on plants: a review. - Ecotoxicol. Environ. Safe. 60: 324-349, 2005.

Parihar P., Singh S., Singh R. et al.: Effect of salinity stress on plants and its tolerance strategies: a review. - Environ. Sci.Pollut. R. 22: 4056-4075, 2015.

Parvin S., Lee O.R., Sathiyaraj G. et al.: Spermidine alleviates the growth of saline-stressed ginseng seedlings through antioxidative defense system. - Gene 537: 70-78, 2014.

Peltzer D., Dreyer E., Polle A.: Differential temperature dependencies of antioxidative enzymes in two contrasting species. Plant Physiol. Bioch. 40: 141-150, 2002.

Rao G.G., Rao G.R.: Pigment composition and chlorophyllase activity in pigeon pea (Cajanus indicus Spreng) and Gingelley (Sesamum indicum L.) under $\mathrm{NaCl}$ salinity. - Indian J. Exp. Biol. 19: 768-770, 1981.

Ravindran K.C., Venkatesan K., Balakrishan V. et al.: Restoration of saline land by halophytes for Indian soils. - Soil Biol. Biochem. 39: 2661-2664, 2007.

Romero-Aranda R., Soria T., Cuartero J.: Tomato plant-water uptake and plant-water relationships under saline growth conditions. - Plant Sci. 160: 265-272, 2001.

Rosales M.A., Rios J.J., Castellano R. et al.: Proline metabolism in cherry tomato exocarp in relation to temperatura and solar radiation. - J. Hortic. Sci. Biotech. 82: 739-744, 2007.

Roy P., Niyogi K., SenGupta D.N. et al.: Spermidine treatment to rice seedlings recovers salinity stressinduced damage of 
plasma membrane and PM-bound $\mathrm{H}^{+} \mathrm{ATPase}$ in salt-tolerant and salt-sensitive rice cultivars. - Plant Sci. 168: 583-591, 2005.

Ruiz D., Martínez V., Ceradá A.: Citrus response to salinity: growth and nutrient uptake. - Tree Physiol. 17: 141-150, 1997.

Santa-Cruz A., Acosta M., Perez-Alfocea F. et al.: Changes in free polyamine levels induced by salt stress in leaves of cultivated and wild tomato species. - Physiol. Plantarum 101: 341-346, 1997.

Setlík S.I., Allakhveridiev L., Nedbal E. et al.: Three type of photosystem II photoinactivation. I. Damaging process on the acceptor side. - Photosynth. Res. 23: 39-48, 1990.

Sfakianaki M., Sfichi L., Kotzabasis K.: The involvement of LHCII-associated polyamines in the response of the photosynthetic apparatus to low temperature. - J. Photoch. Photobio. B 84: 181-188, 2006.

Shalhevet J.: Plants under salt and water stress. - In: Fowden L., Mansfield T., Stoddart J (ed.): Plant Adaptation to Environmental Stress. Pp. 133-154. Chapman and Hall, LondonGlasgow-New York-Tokyo-Melbourne-Madras. 1993.

Sharma D., Dubey A., Srivastav M. et al.: Effect of putrescine and paclobutrazol on growth, physiochemical parameters., and nutrient acquisition of salt-sensitive citrus rootstock Karna khatta (Citrus karna Raf.) under $\mathrm{NaCl}$ Stress. - J. Plant Growth Regul. 30: 301-311, 2011.

Sheokand S., Kumari A., Sawhney V.: Effect of nitric oxide and putrescine on antioxidative responses under $\mathrm{NaCl}$ stress in chickpea plants. - Physiol. Mol. Biol. Plants 14: 355-362, 2008.

Singh A.K, Dubey R.S.: Changes in chlorophyll $a$ and $b$ contents and activities of photosystems I and II in rice seedlings induced by $\mathrm{NaCl}$ - Photosynthetica 31: 489-499, 1995.

Stevens J., Senaratna T., Sivasithamparam K.: Salicylic acid induces salinity tolerance in tomato (Lycopersicon esculentum cv. 'Roma'): associated changes in gas exchange, water relations and membrane stabilisation. - Plant Growth Regul. 49: 77-83, 2006.

Sudhir P., Murthy S.D.S.: Effects of salt stress on basic processes of photosynthesis. - Photosynthetica 42: 481-486, 2004.

Syeed S., Anjum N.A., Nazar R. et al.: Salicylic acid- mediated changes in photosynthesis, nutrients content and antioxidant metabolism in two mustard (Brassica junea L.) cultivars differing in salt tolerance. - Acta Physiol. Plant. 33: 877-886, 2011.

Takahama U., Oniki T.: A peroxidase/phenolics/ascorbate system can scavenge hydrogen peroxide in plant cells. -
Physiol. Plantarum 101: 845-852, 1997.

Todorova D., Sergiev I., Alexieva V. et al.: Polyamine content in Arabidopsis thaliana (L.) Heynh during recovery after low and high temperature treatments. - Plant Growth Regul. 51: 185191, 2007.

Torrecillas A., Guillaume C., Alarcon J.J. et al.: Water relations of two tomato species under water stress and recovery. - Plant Sci. 105: 169-176, 1995.

Upchurch R.G.: Fatty acid unsaturation, mobilization and regulation in response of stress to plants. - Biotechnol. Lett. 30: 967-977, 2008.

van Kooten O., Snel J.F.H.: The use of chlorophyll fluorescence nomenclature in plant stress physiology. - Photosynth. Res. 25: 147-150, 1990.

Velikova V., Yordanov I., Edreva A.: Oxidative stress and some antioxidant systems in acid rain-treated bean plants: Protective role of exogenous polyamines. - Plant Sci. 151: 59-66, 2000.

Verma S., Mishra S.N.: Putrescine alleviation of growth in salt stressed Brassica juncea by inducing antioxidative defense system. - J. Plant Physiol. 162: 669-677, 2005.

Wang X., Shi G.X., Xu Q.S. et al.: Exogenous polyamines enhance copper tolerance of Nymphoides peltatum. - J. Plant Physiol. 164: 1062-1070, 2007.

Wi S.J., Kim W.T., Park K.Y.: Overexpression of carnation Sadenosylmethionine decarboxylase gene generates a broad spectrum tolerance to abiotic stresses in transgenic tobacco plants. - Plant Cell. Rep. 25: 1111-1121, 2006.

Wimalasekera R., Tebartz F., Scherer G. F.: Polyamines, polyamine oxidases and nitric oxide in development, abiotic and biotic stresses. - Plant Sci. 181: 593-603, 2011.

Wu X., Zhu W., Zhang H. et al.: Exogenous nitric oxide protects against salt-induced oxidative stress in the leaves from two genotypes of tomato (Lycopersicom esculentum Mill). - Acta Physiol. Plant. 33: 1199-1209, 2011.

Yamaguchi K., Takahashi Y., Berberich T. et al.: A protective role for the polyamine spermine against drought stress in Arabidopsis. - Biochem. Biophys. Res. Co. 352: 486-490, 2007.

Zhang L., Zhang Z., Gao H. et al.: Mitochondrial alternative oxidase pathway protects plants against photoinhibition by alleviating inhibition of the repair of photodamaged PSII through preventing formation of reactive oxygen species in Rumex K-1 leaves. - Physiol. Plantarum 143: 396-407, 2011.

Zhao L.Q., Zhang F., Guo J.K. et al.: Nitric oxide functions as a signal in salt resistance in the calluses from two ecotypes of reed. - Plant Physiol. 134: 849-857, 2004. 